(I) Unit Processes in Organic Synthesis By P. H. Groggins (Editor-in-Chief).

(Chemical Engineering Series.) Second edition. Pp. xiii +769 . (New York and London: McGraw-Hill Book Co., Inc., 1938.) $36 s$.

(2) Industrial Chemistry

By William Thornton Read. Second Edition. Pp. ix +605 . (New York: John Wiley and Sons, Inc.; London: Chapman and Hall, Ltd., 1938.) 258. net. 7 HE very rapid development of the chemical industry in the United States, which country probably leads the world to-day in this respect, has brought about a demand for trained chemists both on the research and on the factory side. The magnitude of the profession is witnessed by the fact that the American Chemical Society has a membership of more than 21,000 and has enlisted more than 2,000 new members per annum for the last three years. It is becoming customary for students entering on the factory side to take a course in chemical engineering. It was stated last summer that rather more than half the chemical graduates do this. In consequence there is a demand for chemical engineering literature both of a general and a specific character, and to-day America is well served in this respect. The demand for such books enables them to be kept up to date, an important factor in a rapidly developing science.

Both these books are second editions, that of Groggins after four years. It deals with unit processes in the organic industries, many of the individual chapters being contributed by experts, as is now the custom. The new enlarged edition is likely to enhance the reputation of the work.

Read's book has likewise received expert criticism, the individual chapters having been sent to more than a hundred authorities in the particular fields. The sections relate to individual branches of the industry, a wide range being included. With these two books on his shelves the trained chemist is well equipped to tackle problems in any branch of the chemical industry.

\section{Summable Series and Convergence-Factors}

By Prof. Charles N. Moore. (American Mathematical Society, Colloquium Publications, Vol. 22.) Pp. vi +105 . (New York City : American Mathematical Society, 1938.) 2 dollars.

7 HIS work is designed to give a systematic treatment of convergence-factor theorems, where these consist of results concerning the relationship between a definition based on mean-values and a formally distinct definition in terms of convergencefactors. For all the methods of summing divergent series in general use may be classified as either meanvalue or convergence-factor methods, and to any method of either type, a formally equivalent method of the other type can be constructed. The range of validity of these methods is approximately the same in most cases ; and where there is a difference, it will usually be in favour of the convergence-factor form.

Here, two types of convergence-factors are considered. Those of Type I have, as sole object, the maintenance and production of convergence; while those of Type II may be used to obtain the sum of a series. In this most instructive work, both types of convergence-factors are examined; and the theory is developed for multiple series of any order, as well as for simply-infinite series. By means of the use of the Nörlund, instead of the Cesáro means, the theory developed here is more general than that found in most of the available literature on the subject. Thus, many previous results appear here as special cases of the theorems provedparticularly in the third, fourth and fifth chapters.

A. v. Z.

\section{Rezeptbuch des Alltags}

Von Dr. Hermann Römpp. Auflage 3. Pp. 349. (Stuttgart: Franckh'sche Verlagshandlung, 1937). 8.50 gold marks.

$7 \mathrm{HE}$ word rezept is liberally interpreted, and this

book includes prescriptions for dealing with all the problems that are likely to arise in an ordinary household. It gives directions for making emetics, hair dyes, shampoos, face creams, eau de Cologne, mouth washes, shaving soap, alcoholic drinks, boot polish and about ten kinds of ink, and for treating colds, warts, nose-bleeding, sea-sickness, heat-spots, sunburn and indigestion. Sections are devoted to the keeping of horses, cows, dogs and cats, and to getting rid of mice, rats, earwigs, ants, snakes and a host of other pests that afflict houses and gardens. There are sections on gardening, photography, food and clothes. The information appears to be accurate and up to date.

\section{A Course of Physics}

By Prof. Henry A. Perkins. Pp. ix +820 . (London, Glasgow and Bombay: Blackie and Son, Ltd., 1938.) 15s. net.

DROF. PERKINS, of Trinity College, Hartford, has written a text-book of elementary physics covering more ground than is usual. His aim has been to give the student a substantial grasp of physical principles rather than to describe phenomena. Simple algebra and trigonometry have been freely used because most students find a concise symbolic statement easier to grasp than a verbal one. Modern physical ideas have been treated as fully as is feasible in a course of this kind, and nearly eighty pages have been devoted to 'corpuscular physics'. The book should prove suitable for an intermediate science examination in Great Britain.

\section{The Cradle of the North Wind}

By A. S. T. Godfrey. Pp. xi +234 . (London : Methuen and Co., Ltd., 1938.) 8s. 6d. net.

7 HIS charmingly naive book gives a glimpse of the fun which, according to the author, may be derived from roughing it in the Arctic and from killing its animals, always with the proviso that there is not too much "scientific nonsense" about. It must, however, be remembered that the penalty for a frivolous attitude of mind towards the polar regions is very likely to be death, and not for one's self alone: the ice is not suitable for a kindergarten. It is a little surprising that such a book should presumably have been sanctioned by the Oxford University Exploring Ciub. J. E. HamrLtoN. 